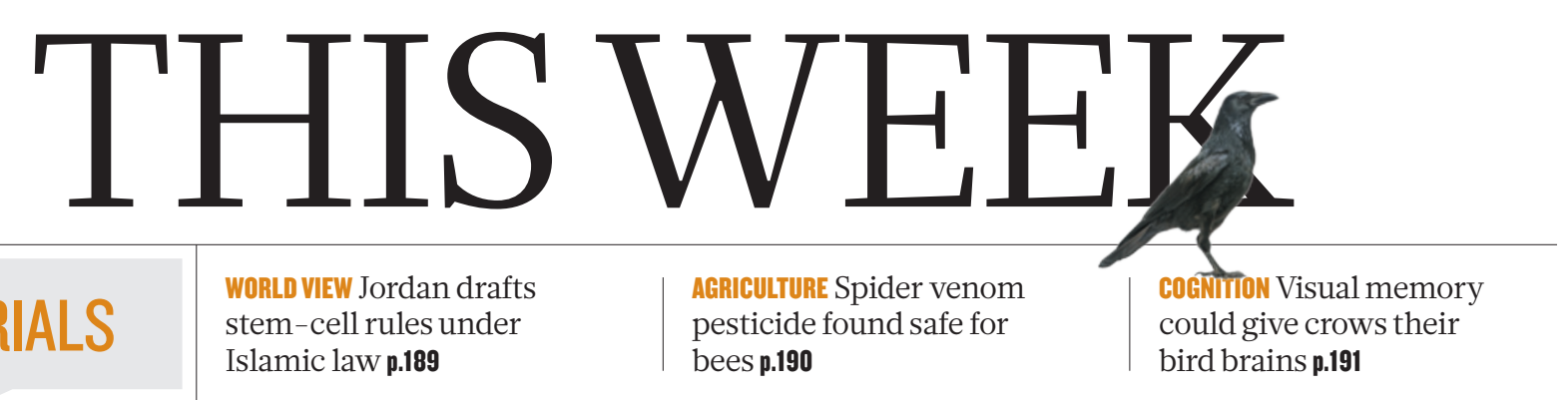

\title{
A growing problem
}

Without careful stewardship, genetically engineered crops will do little to stop the spread of herbicide-resistant weeds.

$\mathrm{P}$ almer pigweed (Amaranthus palmeri) is not a weed to trifle with. It can reach more than 2.5 metres tall, grow more than 6 centimetres a day, produce 600,000 seeds and has a tough, woody stem that can wreck farm equipment that tries to uproot it.

It is also becoming more and more resistant to the popular herbicide glyphosate.

The first such resistant population was confirmed in 2005 in a cotton field in Georgia, and the plant now plagues farmers in at least 23 US states. It is just one of many resistant weeds marching through the world.

The US Environmental Protection Agency (EPA) is trying to learn from the pigweed experience, and wants to limit the damage caused by the latest wave of weed control. It deserves credit and support.

There is broad agreement that the spread of these resistant plants has its roots in the widespread adoption of crops engineered to be resistant to glyphosate. By the time these genetically engineered crops were released in the mid-1990s, farmers had been battling herbicideresistant weeds for decades. But glyphosate was thought to be a particularly challenging herbicide for weeds to overcome. Few cases of resistance had been seen.

That was set to change: by 2012, glyphosate-resistant weeds had infested 25 million hectares of US cropland. They have also appeared in other countries that have embraced glyphosate-tolerant crops, including Australia, Brazil and Argentina. Blanketing crops year after year in the same herbicide is the perfect way to foster resistant weeds.

Chemical companies have come up with a solution: crops engineered to tolerate multiple herbicides. The likelihood of a weed becoming resistant to more than one chemical, they claim, is very small. And, in an eerie echo of the 1990s discussion around glyphosate tolerance, some even point out that one of the other herbicides being targeted - the choline salt of an old chemical called 2,4-D - has been used for decades with little sign of resistance.

It is a flawed argument. Stacking up tolerance traits may delay the appearance of resistant weeds, but probably not for long. Weeds are wily: farmers have already reported some plants that are resistant to more than five herbicides. And with glyphosate-resistant weeds already in many fields, the chances of preventing resistance to another are dropping.

Crops resistant to multiple herbicides could be useful. But scientists are concerned that farmers will rely too heavily on the chemicals, and neglect other ways to combat the resistance threat. Those include using a mixture of herbicides that are specific to a field's invaders, rotating crops and moderate tilling - practices together known as integrated weed management. A farmer making good money in the age of biofuel crop subsidies may be loath to switch to a different crop. And farmers may be hesitant to invest the money needed to properly manage weeds, when their farms could end up infested with weeds from less-assiduous neighbours.

This is where the EPA comes in. In its draft assessment of the

blend of herbicides to be used, it calls for the manufacturer - Dow AgroSciences of Indianapolis, Indiana - to monitor the emergence of resistant weeds and report them to the agency. The EPA will then have the power to impose restrictions on Dow or on the use of the herbicide if it deems this necessary.

The EPA is soliciting comments on the draft assessment from the public until the end of June. It offers sensible precautions, but it could

"The EPA proposes sensible precautions, but it could do much more." - herbicides have limits on how often they can be used for environmental reasons. Such measures would be a sign that regulators and farmers alike have realized the consequences of underestimating the ability of weeds to develop resistance. $\square$

\section{Good practice}

\section{Standardized procedures and analyses should} help to get stem-cell therapies to the clinic.

$\mathrm{U}$ nethical procedures, exploitation and inflated promises, that is what generally makes the headlines - and so it is with regenerative medicine and stem cells. Media reports have left the distinct impression that the research is rather dubious.

First is the long-standing controversy over the source material: human embryos. Research banned by the most powerful man in the world - as US President George W. Bush was when he stopped federal support for such work in 2001 - must be a bit dodgy, right? Then there are the regular reports of companies that are exploiting vulnerable - and often seriously ill - patients with promises of expensive, but unproven, miracle cures.

But behind the headlines is a different story. Scientists doing the systematic research needed to get cellular therapies into the clinic are finally making headway. Trials are now under way for treating an eye disorder called macular degeneration using retinal cells. And a trial using immature glial cells to treat spinal-cord injury has restarted after the company running it pulled out in 2011 (see Nature 510, 18; 2014).

It has taken many years to get to the starting line, but shortcuts are simply not possible, despite charlatan claims. It takes time to 
learn how to coax stem cells - either from human embryos or from reprogrammed adult cells known as induced pluripotent stem (iPS) cells - to develop into the right sort of replacement cell. It also takes time to work out how to get these cells to integrate into the host tissue and to function. And the steps required to work out how many replacement cells need to be delivered, and how to deliver them safely, cannot be rushed.

The eye and spinal cord are relatively isolated systems. Much will be learnt from them, but the brain and heart are altogether more complicated. Fixing damage in these systems is crucial, however, because together they provide the biggest disease burden in developed countries.

Happily, clinical trials are on the horizon. Treatments for Parkinson's disease are just a few years away from clinical testing. And some for Huntington's disease may not be far behind.

Taking any radical therapy into humans requires caution. Ideally, researchers should be able to use data from a patient in one trial to refine the approach for one in another. So a decision by the Global Force for Parkinson's Disease, or G-force, to bring together teams from Europe, the United States and Japan to define standards for cell preparation and patient selection and monitoring for future trials is particularly welcome (see page 195).

The G-force seems to have learnt the lessons of moving research to the clinic too fast and in isolated teams. Multiple trials of cells derived from fetal brains to treat Parkinson's disease began in the late 1980s, but stopped in 2003 because the outcomes were an uninterpretable mishmash. And trials using adult stem cells to treat heart failure have shown wildly varying outcomes (see Nature 509, 15-16; 2014), perhaps owing in part to a lack of good preclinical data. But systematic research has now shown that heart cells derived from human embryonic stem cells can engraft into damaged primate hearts and synchronize their beats to it, at least to some extent. Some of the monkeys developed arrhythmias, showing that the technique still needs improvement. The principle of the therapy has been proven, however, which gives confidence that clinical trials may become possible.

"News reports
need to be
careful not
to overhype
the potential
of cellular
therapies."

Designing trials to agreed standards will ensure that researchers can understand why any one patient benefited, or failed to benefit, from the treatment. This will magnify the efficiency of the trials and speed up the development of therapies. It is a model that deserves to be widely copied.

News reports need to be careful not to overhype the potential of cellular therapies. As the field inches towards clinical testing, it is important that researchers clearly communicate to the media what the therapies are likely to achieve - and what they are not. Early trials are unlikely to show cures, but that does not diminish their value: even small improvements in quality of life are important to a person with a serious disability. A blind person who becomes able to discern light from shade, a paralysed person who regains some feeling in a limb and a person with advanced Parkinson's disease who can walk independently, if not normally - each will think it worthwhile.

Like all new therapies, stem-cell repair will improve through trial and error. These approaches promise more trial and, hopefully, fewer errors.

\section{Open goal}

\section{International researchers can help to improve the scientific enterprise in South America.}

$\mathrm{P}$ roductivity in offices and labs around the world will probably slip a little during the next month, as football fans tune in to watch the 2014 FIFA World Cup, which starts in Brazil this week. Four years ago, nearly half the world's population tuned in at some point during the tournament. And as the world focuses its attention on Brazil, Nature has taken the opportunity to widen the view with our special issue on science in South America (see page 201). The package of articles and commentaries details some of the success stories on the continent as well as the substantial challenges faced by researchers there as they seek to build scientific institutions in the wake of decades lost to dictatorships.

They need not struggle alone. From London to Boston to Tokyo, individual scientists and larger organizations in the developed world can offer significant help to South American countries. When Nature asked leading South American scientists what kind of assistance would bring tangible benefits, the answers invariably clustered around two key requests to their international colleagues: host young scientists in your laboratories, and come to visit South American researchers.

The flow of students from South America to the United States and Europe has grown in recent years but remains a trickle. Brazil sent fewer than 11,000 undergraduate and graduate students to the United States in 2013 - less than Turkey and Vietnam, countries with much smaller populations and economies. The tally for all students sent to US universities from Latin America and the Caribbean was less than one-third of the number sent by China.

Many South American scientists called on their northern colleagues to recruit more graduate students and postdoctoral

scientists from the continent. Even short visits of three to six months can help to train a young scientist. But the exchanges have to be done in a way that does not contribute to the brain drain that has lured many leading researchers to permanent positions in the United States and Europe (see pages 207 and 213). One solution is to provide start-up funds for researchers returning to South America. For example, after postdoctoral training in the United States, Lino Barañao received support from the Rockefeller Foundation to establish his lab at home in Argentina, where he is now the minister of science, technology and innovative production.

Travel needs to go both ways. According to South American researchers, too few scientists visit their continent to spend time in labs, give lectures and attend meetings. Even virtual visits, through video conferences, would help.

The networking requests go beyond the wish to trade research methods and results. Scientists in South America want to know how to select the best people and how to improve coordination between universities and industry. Many called for help in improving science-evaluation processes (see page 209). In Brazil, for example, assessments too often reward quantity over quality.

Investments in sending researchers back and forth can yield longterm dividends. In 1990, Argentine molecular biologist Eduardo Arzt started a fellowship at the Max Planck Institute for Psychiatry in Munich, Germany. After returning to Argentina, Arzt continued to collaborate with Max Planck colleagues - a connection that was key when the society was looking to expand its international programs. In 2011, it established its first South American partner institute in Buenos Aires, run jointly with Argentina's Council for Scientific and Technological Research, and with Arzt as director. Several of the research groups at the institute are led by Argentine scientists lured back from overseas by the opportunity to do toptier science.

$\rightarrow$ NATURE.COM To comment online, click on Editorials at: go.nature.com/xhunqu
Football fans in South America are used to seeing top players leave for abroad. Efforts to reverse the flow, in science as in sport, face great challenges. But they are a worthwhile goal. 